\title{
Assessing the Effect of Climate Oscillations and Land-use Changes on Streamflow in the Central Spanish Pyrenees
}

Plans to increase the amount of irrigated land in Mediterranean countries should consider how changes in climate and land-use affect water resources. In this study, both precipitation and temperature were used to analyze regional trends in discharge in the basins of the Central Spanish Pyrenees since the mid-20th century. Annual variations in the relationship between precipitation and discharge suggested that discharge was relatively lower in the second half of the study period, coinciding with major changes in land use. On a monthly scale, precipitation increased significantly in October, April, and July, and decreased in March, and temperature increased in January and February and decreased in April. Nevertheless, discharge has decreased significantly in most months in the past 50 years. Land-use and plant-cover changes are the only nonclimatic factor that can explain the loss of around $30 \%$ of the average annual discharge.

\section{INTRODUCTION}

Mountains hold key water resources, especially in Mediterranean areas where precipitation is scarce, evapotranspiration is intense, and there is a strong contrast between humid and dry seasons. Mediterranean mountains have been considered as "islands" of humidity since they provide most of the discharge to the main rivers. These islands are surrounded by semiarid areas which provide low crop yields under dry-farming systems. Irrigation has been used to increase and diversify these crops to the extent that Mediterranean agriculture now depends on water supplied by reservoirs and canals. A good example is the Ebro Depression, NE Spain, where recent developments in irrigation have affected around $7400 \mathrm{~km}^{2}$. Now the new Spanish Hydrological Plan aims to increase this area, especially in the Ebro Depression, and transfer $0.105 \mathrm{Mm}^{3}$ of water from the Ebro basin to the Mediterranean coast to supply highly productive areas. We need methods to carefully forecast both the evolution of these water resources and water demand.

Under natural conditions, the water balance of a river basin can be represented by the water balance equation:

$$
R=P-\left(E T+\Delta_{\text {soil }}+\Delta_{\text {snow }}+\Delta_{\text {aquifers }}\right) \quad \text { Eq. } 1
$$

where $R$ is runoff or water yield, $P$ is precipitation or water input into the watershed, and the term in brackets is water loss, evapotranspiration $(E T)$, including interception, difference in soil water storage between the end and the beginning of the period $\left(\Delta_{\text {soil }}\right)$, difference in water storage in the snowpack $\left(\Delta_{\text {snow }}\right)$, and difference in water storage in the aquifers $\left(\Delta_{\text {aquifers }}\right)$.

Figure 1. Location of the study area.

1: Gauge stations.

2: Weather stations.
The terms $\Delta_{\text {soil }}$ and $\Delta_{\text {snow }}$ can be ignored when evaluating big catchments on a yearly basis under a Mediterranean climate with dry summers. It is assumed that the soil and snow water storage are almost completely exhausted by the end of the hydrological year. The term $\Delta_{\text {aquifers }}$ can also be neglected when the global water balance is not greatly affected by subterranean circulation. Equation 1 then becomes:

$$
R=P-E T
$$

Thus, the main variables that control water yield in a basin are precipitation, interception and evapotranspiration. These factors are closely related to changes in climate and land-use/plant cover. Many studies have focused on the former despite works on land use by Shachori et al. (1) and Hewlett (2). Nevertheless, a number of recent reports on basins consider the hydrological effects of felling and clearcutting (see 3-8), reforestation (9-11), and forest fires (12). All of these effects are more difficult to assess as the size of the basin increases, due to the large variability of rainfall and basin characteristics (13).

The effects of climate and land use should be clearly separated when managing and forecasting discharge. This is especially true in Mediterranean areas which are affected by rapid economic changes and are extremely dependent on mountain water resources. This paper deals with the role of climate evolution and land-use changes on the evolution of water resources in the Central Spanish Pyrenees. It also provides a good example of the challenges involved in managing water.

\section{THE STUDY AREA}

The study area covered $7430 \mathrm{~km}^{2}$ in the Central Spanish Pyrenees between the Esca and Noguera Ribagorzana rivers (Fig. 1). Altitudes range from 500 to more than $3000 \mathrm{~m}$ a.s.l., with a very contrasted relief (14). The climate is influenced by the Atlantic and Mediterranean and the effect of macrorelief on precipitation and temperature. The average annual precipitation in the Central Ebro Depression is approximately $300 \mathrm{~mm}$. The average annual temperature ranges from $13-15^{\circ} \mathrm{C}$. Annual precipitation in the mountains exceeds $600 \mathrm{~mm}$ and sometimes 2000

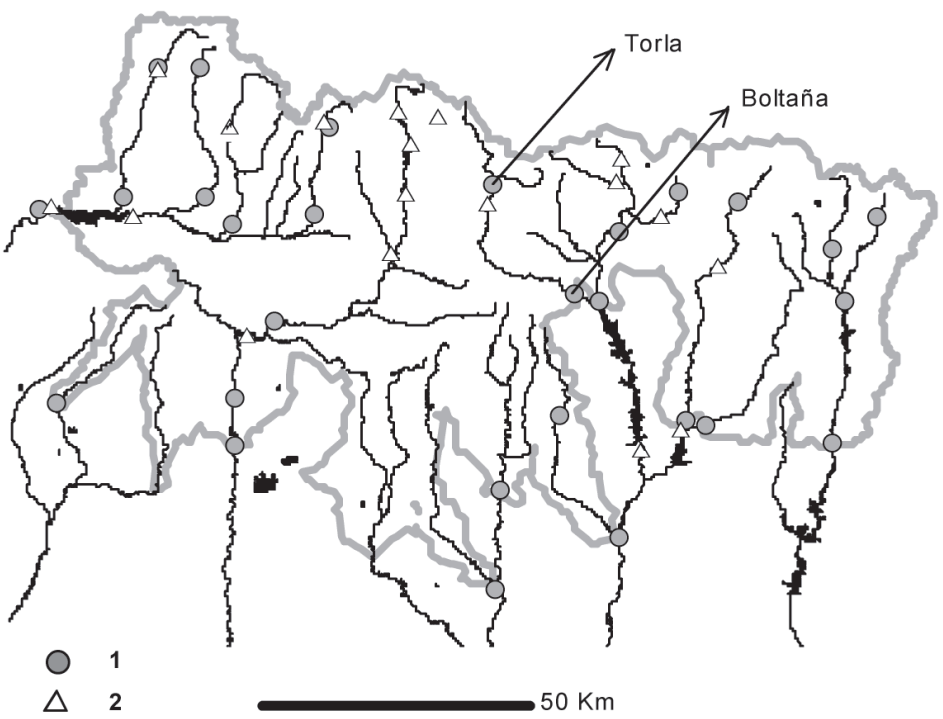


$\mathrm{mm}$ at the highest divides. Most precipitation falls during the cold season. Summers are relatively dry in the Pyrenees and very dry in the Ebro Depression. Above $1600 \mathrm{~m}$ a.s.l. most precipitation falls as snow during the cold season (November-May). The $0^{\circ} \mathrm{C}$ isotherm is located at $2726 \mathrm{~m}(15)$.

The influence of snow on river flow is assessed by headwater gauging stations (16). In winter, the discharge is low and regular, despite frequent rainfalls. In spring, it increases due to snowmelt and frequent rainfalls, and then quickly decreases until September as the snow reserves are depleted. In autumn there are intense rainstorms. Downstream, the peak spring discharges decrease in intensity and the low winter discharges increase, as is the case of the Ara River (Fig. 2). All the main Pyrenean rivers are regulated by reservoirs that ensure the water supply to the irrigated areas of the Ebro Depression. The total reservoir capacity represents $59 \%$ of the annual water resources. Now, under the National Hydrological Plan, there are plans to increase the size of the reservoirs or build new ones.

At the beginning of the 20th century, many sunny hillslopes were used to grow wheat and barley, alternating with fallow. Forested areas were also affected by overgrazing and fire, which was frequently used to improve the quality of grasslands. Farmed areas represented about $30 \%$ of the territory below $1600 \mathrm{~m}$ a.s.1. They now occupy less than $2 \%$ since most have been abandoned since the 1940 s and colonized by dense shrub (17). In the Upper Aragón basin (2141 $\mathrm{km}^{2}$ in total), abandoned fields occupy $471 \mathrm{~km}^{2}$ or $22 \%$ of the area, $64 \%$ of which has evolved into forest, $29 \%$ shrubs and $7 \%$ grazing meadows.

The study area includes several river basins immediately upstream of the main reservoirs and water abstractions, in order to reduce the human impact brought about by water storage, consumption and returns, which greatly disturb the water balance. In this area, human density is low and water consumption was considered irrelevant.

\section{METHODS}

A hydrologic and climatic data base was developed using the information from 18 weather stations and 28 gauge stations in the study area (Fig. 1). The longest series started in 1920, but most records began in 1945 . We only used gauge stations upstream of the major reservoirs and water abstractions, and records from 1945 to 1995 for the main analysis.

The best way to measure the influence of changes in climate and land cover on runoff is by using quantitative data on the revegetation process throughout the century. Unfortunately, this is quite difficult. A lot of information exists for the Pyrenees but it is mostly qualitative or point-in-time data. It is much more difficult to obtain a continuous quantitative index of the revegetation process. For this reason, we could not produce a model that included both climatic series and changes in land cover. Nevertheless, we assumed that these were the 2 main factors that affected runoff in the study area and constructed a simple hydro-climatic model to assess changes in land cover by analyzing the residuals of the model.

The 18 rainfall and temperature series and the 28 discharge series were converted into 3 yearly regional indexes that summarized the global variation of the variables in the whole region. The regional index was defined as the normalized average of the normalized variables and was developed in 3 steps:

i) Normalization of the original yearly series (total precipitation, average temperature and total runoff) by subtracting the 1945-1995 mean and dividing by the 1945-1995 standard deviation.

ii) Calculation of the yearly averages of each variable.

iii) Normalization of the averaged time series.

The result was a synthetic index with a zero mean and one unit standard deviation expressed in $\mathrm{z}$-scores that summarized
Figure 2. Regime of the Ara River at Torla and Boltaña; 1945-1995.

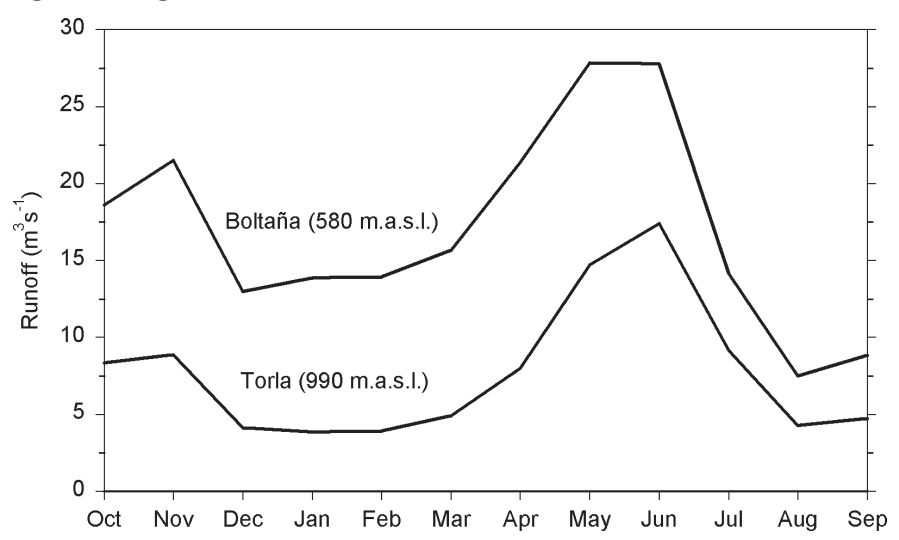

the regional anomalies above or below the average and allowed us to compare the 3 climatic and hydrologic variables.

An adequate modelling approach arose spontaneously from the water balance equation shown above (Eq. 2). Thus, total losses were easily deduced once $R$ and $P$ were known. However, it was difficult to estimate the real precipitation over such a large area since the uncertainty was greater than the expected effect of the nonclimatic factors. For this reason, alternative approaches were explored. The use of linear relationships between regional climatic and runoff indexes offered a very simple framework with several advantages:

i) ease of calculation and interpretation;

ii) possibility of interpreting the residuals of the model as the unknown element in the balance approach (losses);

iii) possibility of studying the changing relationship between the variables through time;

$i v)$ after normalization, an easier comparison of precipitation, temperature and runoff since they converged to the same scale.

Thus, we performed a multiple linear regression between the climatic (precipitation and temperature) and runoff indexes. Residual analysis included a trend analysis based on Spearman's rank correlation statistic.

Regional monthly indexes were also developed as above to study the effects of land cover on the monthly runoff regime. All monthly synthetic series were tested against linear trends from 1945-1995 using Spearman's rank correlation statistic. The comparison between monthly trends in climatic and runoff series also helped to explain the impact of nonclimatic factors, such as revegetation.

\section{RESULTS}

Figure 3 shows the regional annual indexes for precipitation, temperature and discharge, relevant since 1940, which involved several weather and gauging stations. All 3 variables underwent important temporal fluctuations. There was a relatively dry period between 1940 and 1957, another humid period between 1957 and 1980 and finally a dry period.

The regional discharge index was a faithful representation of the precipitation, with the same humid and dry periods.

There was also important variation in the regional temperature index, with a warm period around 1945, a cooler period between 1950 and 1980 and a warmer period after 1980 .

The relationship between regional precipitation and discharge changed throughout the study period. The precipitation index was lower than the discharge index between 1945 and 1970, and higher after 1970. This suggests that there was a progressive decrease in runoff yield for a given precipitation.

Runoff was predicted by a stepwise multiple regression with precipitation and temperature indices, and time as independent variables. The contribution from the temperature index to the to- 
tal explained variance was not significant $(p>0.05)$ and the final equation was

$$
R=0.591+0.954 P-0.025 t
$$

which explained a large part of the variation $\left(r^{2}=0.939\right)$. The residuals between observed and predicted runoff were randomly distributed in time (Fig. 4).

The inclusion of time in the final equation suggests the existence of other nonclimatic factors to explain changes in runoff. Assuming a constant precipitation, the evaluation of the nonclimatic element can be assessed from Equation 3. Providing that the average runoff from all the rivers was $0.54 \mathrm{Mm}^{3} \mathrm{yr}^{-1}$, and the standard deviation was $0.152 \mathrm{Mm}^{3} \mathrm{yr}^{-1}$, the total loss during the study period was estimated in $0.190 \pm 0.023 \mathrm{Mm}^{3}$. This implied a decrease of around $30 \pm 4 \%$ in 50 years.

Finally, monthly variations in precipitation, temperature and discharge were quite different (Fig. 5) from 1945 to 1995. Precipitation remained stable except in October, April, and July when it increased significantly, and March when it decreased, as in the rest of the Iberian peninsula (18). Temperature had a positive trend in January and February, and negative in April. Other months had nonsignificant trends.

Monthly runoff decreased significantly in February, March, April, May, June, and September. Only October shows a nonsignificant positive trend, related to the increase in precipitation. Since discharge decreased almost every month and there was no negative temporal trend in precipitation (except in March), or positive trend in temperature (except in January and February), another important nonclimatic factor was needed to explain the changing pattern of runoff.

\section{DISCUSSION AND CONCLUSIONS}

In general, 2 main factors govern fluvial discharge: $i$ ) climate (especially precipitation); and ii) land use/plant cover. Both factors affect major hydrological processes such as evapotranspiration, including interception, and determine the compo- nents of the hydrological cycle at the basin scale.

The regional climatic indexes confirmed a climatic cycle of 15-20 years where precipitation and temperature varied between one standard deviation above or below the average values. These climatic "waves" or fluctuations are a common feature worldwide (19-21). Nevertheless, we found no evidence of a clear annual climatic trend since the mid-20th century. There was no temporal trend in annual precipitation, which confirms larger studies of the whole Iberian Peninsula (18). Instead, there was a trend in the regional discharge index. Changes in year-to-year relationships between precipitation and discharge suggested that discharge was relatively lower in the second half than in the first half of the study period. In fact, good correlations were found between precipitation and runoff. This enabled us to construct a linear regression model in which time absorbs a high part of the variance.

Furthermore, there were almost no monthly climatic changes. As seen in Figure 5, the trend in monthly precipitation since 1945 was only significant in October, April, and July (positive), and March (negative), while temperature increased in January and February and decreased in April. Nevertheless, discharge decreased significantly in most months over the last 50 years. The difference between the trends in climate and discharge implies that a nonclimatic, time dependent factor is determining the fluctuations in discharge.

The negative trend in discharge in the Pyrenean rivers coincides with major changes in land management. Since the mid20 th century most cultivated fields in the hillslopes $(22 \%$ of the study area) were abandoned and progressively covered by dense shrub and forests. At the same time, man-induced fires have been reduced drastically. This represents a progressive, intense reduction in runoff as found in other experimental studies in the Pyrenees $(17,22,23)$, where farmed plots have been compared to both dense shrub and meadow plots. Studies in the Eastern Pyrenees have also shown that interception in young forests that colonize old abandoned fields represents approximately $24 \%$ of the annual precipitation (24). A similar trend is observed in subalpine grasslands where a decrease in intensive livestock
Figure 3. Temperature, precipitation and runoff indexes, in normalized standard deviations.

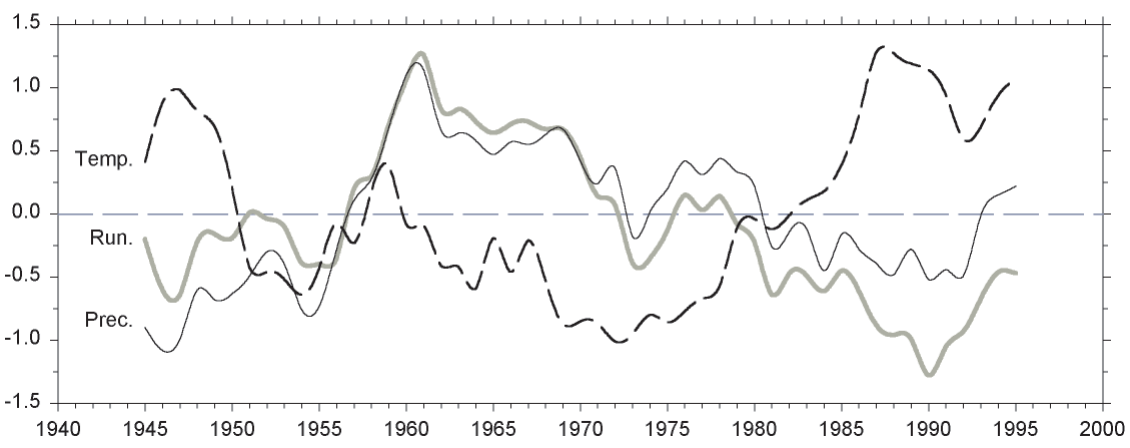

Figure 4. Predicted and observed runoff indexes, and temporal trend of the residuals.

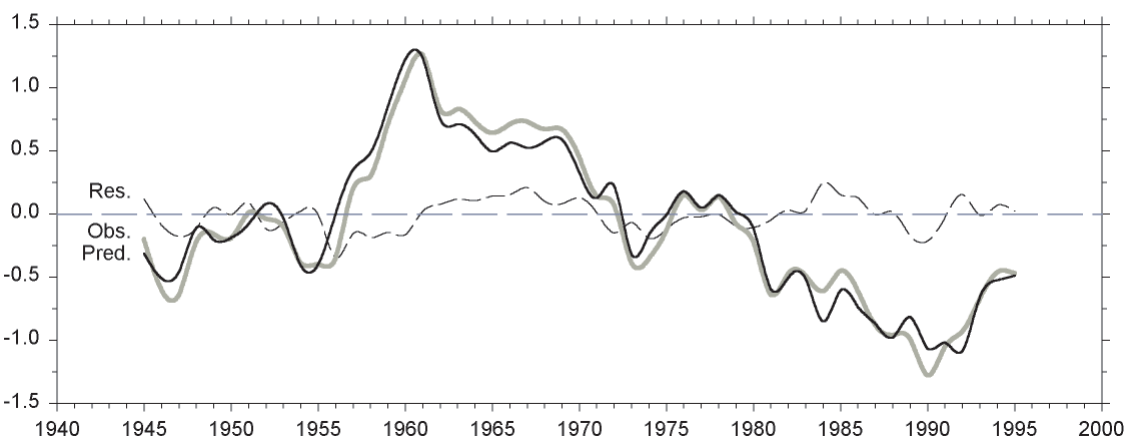

Figure 5. Monthly trends of precipitation, temperature and runoff indexes (Spearman Rank Correlation Statistic). The significant trend at $\alpha=0.05$ is shown in dark grey.

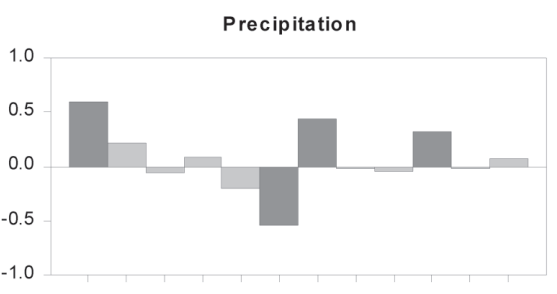

Oct Nov Dec Jan Feb Mar Apr May Jun Jul Aug Sep
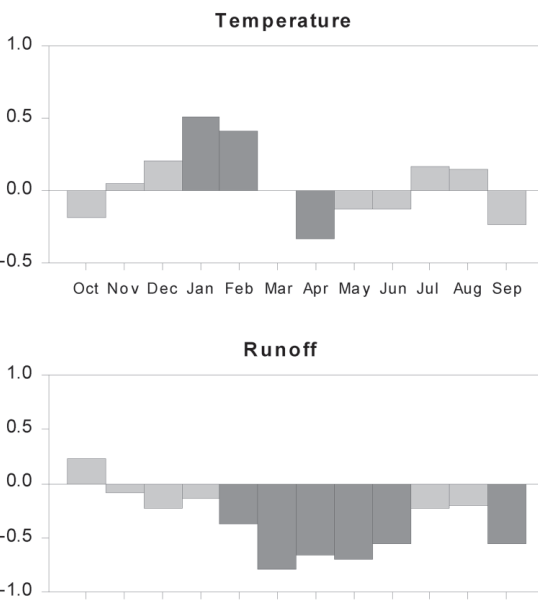

Oct Nov Dec Jan Feb Mar Apr May Jun Jul Aug Sep 
management in the past 30 years has allowed higher herbaceous plants to grow and a slow colonization by scrubs and trees (25). Geomorphological studies in the Central Pyrenees have shown that reforestation after the abandoning of farmland clearly reduces the intensity and frequency of floods (10).

Studies in USA midwestern basins show that changes in land use account for about two-thirds of the fluctuations in the mean flow and precipitation for the other third (26). In the southeastern United States, Trimble and Weirich (27) found that "small increases in forest cover significantly reduce water yields in large river basins" (between 4 and 21\%). In New Zealand, reforestation by Pinus radiata reduces runoff by $25-30 \%$, and the same trend is observed in soil water contents compared with pastureland (9). In a Mediterranean-type climate (Cevennes région, SE France), reforestation reduced peakflows by about $20 \%$ (7). Clearcutting produces the opposite effect, as demonstrated by Bosch and Hewlett (3) in 94 worldwide catchments, and Sahin and Hall (28) for 145 catchments. In Japan, Nakano (29) reported that the removal of forest cover increased annual runoff from 8 to $24 \%$ and peak flow from 69 to $114 \%$. Recently, Zhang et al. (30) have presented results from over 250 catchments worldwide which confirm that annual evapotranspiration is generally greater for forested than for unforested catchments, the difference being larger in high rainfall areas. Gallart et al. (31) found that the spatial distribution of soil humidity in catchments of the Eastern Pyrenees is mainly related to plant cover. Forested areas are, in general, dryer than meadows due to higher evapotranspiration. Studies using models also emphasize the importance of landuse and forest cover $(7,32)$.

In this study, changes in land-use/plant cover reduced water yield by about $30 \%$ between 1945 and 1995. This figure is only a rough estimation, but confirms the importance of land management on runoff generation and its use as a key factor to forecast water yield (28).

\section{References}

1. Shachori, A., Rosenzweig, D. and Poljakoff-Mayber, A. 1967. Effect of Mediterranean vegetation on the moisture regime. In: International Symposium on Forest Hydrology, Sopper, W.E. and Lull, H.W. (eds). Pergamon Press, Oxford, pp. 291-310.

2. Hewlett, J.D. 1982. Principles of Forest Hydrology. The University of Georgia Press, Athens, $180 \mathrm{pp}$.

Bosch, J.M. and Hewlett, J.D. 1982. A review of catchment experiments to determine the effect of vegetation on water yield and evapotranspiration. J. Hydrol. 55, 3-23.

4. Hornbeck, J.W., Adams, M.B., Corbett, E.S., Verry, E.S. and Lynch, J.A. 1993. Longterm impacts of forest treatments on water yield: a summary for northeastern USA. $J$. Hydrol. 150, 323-344.

Cornish, P.M. 1993. The effects of logging and forest regeneration on water yields in a moist eucalipt forest in New South Wales, Australia. J. Hydrol. 150, 301-322.

6. Jones, J.A. and Grant, G.E. 1996. Peak flow responses to clearcutting and roads in small and large basins, Western Cascades. Water Resources Res. 32, 959-974.

7. Cognard-Plancq, A.L., Marc, V., Didon-Lescot, J.F. and Normand, M. 2001. The role of forest cover on streamflow down sub-Mediterranean mountain watersheds: a modof forest cover on streamflow down sub-M
elling approach. J. Hydrol. 254, 229-243.

8. Lewis, J., Mori, S.R., Kappeler, E. and Ziemer, R.R. 2001. Effects of logging on storm peak flows, flow volumes and suspended sediment loads in Caspar Creeke, California. In: Land Use and Watersheds. Human Influence and Geomorphology in Urban and Forest Areas. Wigmosto, M.S. and Burges, S.J. (eds). American Geophysical Union, Washington, pp. 85-126.

9. Pearce, A.J., O'Loughlin, C.V.L., Jackson, R.J. and Zhang, X.B. 1987. Reforestation: On site effects on hydrology and erosion, eastern Raukumara Range, New Zealand. IAHS Publ. 167, 489-497.

10. García-Ruiz, J.M. and Ortigosa, L. 1988. Algunos efectos de las repoblaciones forestales: cambios en la dinámica de los cauces en pequeñas cuencas del Pirineo Central español. Cuat. Geomorf. 2, 33-42. (In Spanish, summary in English).

11. García-Ruiz, J.M. and Ortigosa, L. 1992. Some geomorphological effects of afforestation techniques in the Central Spanish Pyrenees. Geoöko-Plus 3, 37-44.

12. Lavabre, J., Sempere-Torres, D. and Cernesson, F. 1991. Étude du comportement hydrologique d'un petit bassin versant Méditerranéen après la destruction de hydrologique d'un petit bassin versant Méditerranéen après la destruction de
l'écosystème forestier par un incendie. Hydrol. Continentale 6, 121-132. (In French, l'écosystème forestier
summary in English)

13. Beschta, R.L., Pyles, M.R., Skaugset, A.E. and Surfleet, C.G. 2000. Peakflow responses to forest practices in the western Cascades of Oregon, USA. J. Hydrol. 233, 102-120.

14. García-Ruiz, J.M., Alvera, B., Del Barrio, G. and Puigdefábregas, J. 1990. Geomorphic processes above timberline in the Spanish Pyrenees. Mountain Res. Develop. 10, $201-$ 214

15. Del Barrio, G., Creus, J. and Puigdefábregas, J. 1990. Thermal seasonality of the high mountain belts of the Pyrenees. Mountain Res. Develop. 10, 227-233.

16. García-Ruiz, J.M., Beguería, S., López-Moreno, J.I., Lorente, A. and Seeger, M. 2001 Los Recursos Hídricos Superficiales del Pirineo Aragonés y su Evolución Reciente. Geoforma Ediciones, Logroño, 192 pp. (In Spanish).

17. Molinillo, M., Lasanta, T. and García-Ruiz, J.M. 1997. Managing mountainous degraded landscapes after farmland abandonment in the Central Spanish Pyrenees. Environ. Mgmt 21,587-597.

18. Serrano, A., Mateos, V.L. and García, J.A. 1999. Trend analysis of monthly precipitation over the Iberian peninsula for the period 1921-1995. Physics Chemistry Earth $24,85-90$.
19. Diaz, H.F., Bradley, R.S. and Eischeid, J.K. 1989. Precipitation fluctuations over global land areas since the late 1800s. J. Geophys. Res. 94, 1195-1210.

20. Hurrell, J.W. and Van Loon, H. 1997. Decadal variations in climate associated with the North Atlantic oscillation. Climatic Change 36, 301-326.

21. Hansen, J. and Lebedeff, S. 1987: Global trends of measured surface air temperature. J. Geophys. Res. 92, 13345-13372.

22. García-Ruiz, J.M., Lasanta, T., Ortigosa, L., Ruiz-Flaño, P., Martí, C. and González, C. 1995. Sediment yield under different land-uses in the Spanish Pyrenees. Mountain Res. Develop. 15, 229-240.

23. García-Ruiz, J.M., Ruiz-Flaño, P., Ortigosa, L., White, S., González, C. and Martí-Bono, C. 1996. Land-use changes and sustainable development in mountain areas: a case study in the Spanish Pyrenees. Landscape Ecol. 11, 267-277.

24. Llorens, P., Poch, R., Latron, J. and Gallart, F. 1997. Rainfall interception by a Pinus sylvestris forest patch overgrown in a Mediterranean mountainous abandoned area. I Monitoring design and results down to the event scale. J. Hydrol. 199, 331-345.

25. Tappeiner, U. and Cernusca, A. 1993. Alpine meadows and pastures after abandonment. Pirineos 141-142, 85-96.

26. Changnon, S.A. and Demissie, M. 1996. Detection of changes in streamflow and floods resulting from climate fluctuations and land use-drainage changes. Climatic Change 32, 411-421.

27. Trimble, S.W. and Weirich, F.H. 1978. Reforestation reduces streamflow in the southeastern United States. J. Soil Water Conserv. 42, 174-276.

28. Sahin, V. and Hall, M.J. 1996. The effects of afforestation and deforestation on water yields. J. Hydrol. 178, 293-309.

29. Nakano, H. 1967. Effects of changes of forest conditions on water yield, peak flow and direct runoff of small watersheds in Japan. In: International Symposium on Forest and direct runoff of small watersheds in Japan. In: International Symposium on Forest

30. Zhang, L., Dawes, W.R. and Walker, G.R. 2001. Response of mean annual evapotranspiration to vegetation changes at catchment scale. Water Resources Res. 37, 701708 .

31. Gallart, F., Llorens, P., Latron, J. and Rabadà, D. 1997. Hydrological functioning of Mediterranean mountain basins in Vallcebre, Catalonia: Some challenges for hydrological modelling. Hydrol. Proces. 11, 1263-1272.

32. Bathurst, J.C., Birkinshaw, S.J., Evans, J. and Francke, S. 1998. Modelo de bases físicas para la predicción de los impactos hidrológicos y la erosión de los suelos provocados por opciones de la gestión forestal en Chile. Chile Forestal 120,1-8. (In Spanish).

33. Funding for this research was provided by the following projects: "Water resources management in a changing environment: the impact of sediment in sustainability" (WARMICE, ENV4-CT98-0789), funded by the European Community, and "Assess(WARMICE, ENV4-CT98-0789), funded by the European Community, and "Assessment of sediment and runoff sources in relation to land-use changes", (HIDROral Mediterranean areas" (PROHISEM, REN2001-2268-C02-01/HID), both funded by CICYT.

34. First submitted 2 Jan. 2002. Revised manuscript received 13 May 2002. Accepted for publication 22 May 2002.

Santiago Beguería is a PhD student at the Department of Soil Erosion and Land-Use Changes of the Pyrenean Institute of Ecology at Zaragoza, Spain. He mainly studies the hydrological and geomorphological effects of land-use and climate changes. His address: Instituto Pirenaico de Ecología, CSIC, Campus de Aula Dei, Apartado 202, 50080-Zaragoza, Spain.

E-mail: sbegueria@ipe.csic.es

Juan Ignacio López-Moreno is a PhD student at the Department of Soil Erosion and Land-Use Changes of the Pyrenean Institute of Ecology at Zaragoza, Spain. He works on water management and the effects of large reservoirs on river regimes. His address: Instituto Pirenaico de Ecología, CSIC, Campus de Aula Dei, Apartado 202, 50080-Zaragoza, Spain.

E-mail: nlopez@ipe.csic.es

Adrián Lorente is a PhD student at the Department of Soil Erosion and Land-Use Changes of the Pyrenean Institute of Ecology at Zaragoza, Spain. He is working on the relationships between global change and mass movements, focusing on the recent evolution of debris flow triggering. His address: Instituto Pirenaico de Ecología, CSIC, Campus de Aula Dei, Apartado 202, 50080-Zaragoza, Spain.

E-mail: adlor@ipe.csic.es

Manuel Seeger is associate professor in geography at the University of Zaragoza. He holds a PhD from Freiburg University in geoecology, and has worked on soil hydrology and the effects of plant cover on the spatial distribution of soil humidity. His address: Department of Geography, University of Zaragoza, Plaza de San Francisco, 50009Zaragoza, Spain.

E-mail: mseeger@ipe.csic.es

José M. García-Ruiz has a PhD in geography and scientific researcher at the Department of Soil Erosion and Land-Use Changes of the Pyrenean Institute of Ecology at Zaragoza, Spain. He is the Head of a research group focused on the relationships between hydrology/geomorphology changes and climate/land-use changes. His current work involves the trends in water resources and soil erosion as a consequence of major changes in mountain land management. His address: Instituto Pirenaico de Ecología, CSIC, Campus de Aula Dei, Apartado 202, 50080-Zaragoza, Spain. E-mail: humberto@ipe.csic.es 